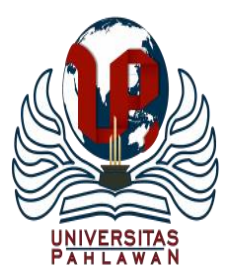

Edukatif : Jurnal Ilmu Pendidikan Volume 3 Nomor 5 Tahun 2021 Halm 2478 - 2487

EDUKATIF: JURNAL ILMU PENDIDIKAN

Research \& Learning in Education

https://edukatif.org/index.php/edukatif/index

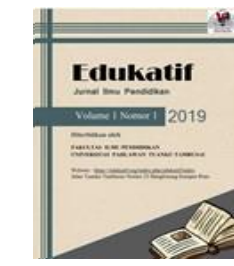

\title{
The Correlation Between Xreading Time Spent and Reading Comprehension \& Efl College Students' Attitudes Towards Xreading
}

\author{
Alvin Nuril Hidayah ${ }^{1 凶}$, Anis Trisusana ${ }^{2}$ \\ Universitas Negeri Surabaya, Indonesia ${ }^{1,2}$

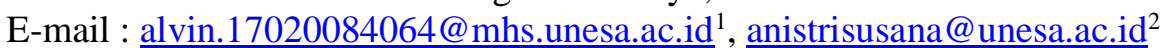

\begin{abstract}
Abstrak
Penelitian ini bertujuan untuk mengidentifikasi korelasi antara waktu membaca dalam XReading dan pemahaman membaca akademik siswa dan mengetahui sikap siswa terhadap XReading. Pendekatan kuantitatif dan kualitatif digunakan dalam menjawab rumusan masalah. Peserta penelitian ini adalah mahasiswa Bahasa Inggris sebagai bahasa asing tahun pertama yang mengikuti program membaca ekstensif (ER) dengan XReading sebagai platform yang digunakan. Data dikumpulkan dari catatan waktu yang dihabiskan oleh siswa di XReading dan skor mereka pada tes pemahaman membaca. Tes ini diadaptasi dari tes pemahaman membaca yang dirancang untuk pembaca tingkat lanjut. Data dianalisis menggunakan Person Correlation dan Linear Regression untuk menentukan bagaimana XReading berkontribusi pada pemahaman membaca. Hasil penelitian menunjukkan bahwa waktu membaca di XReading berkontribusi pada pemahaman membaca sekitar $10 \%$, namun tidak ada korelasi yang signifikan antara kedua variabel. Selain itu, kuesioner dan wawancara Skala Likert dianalisis menggunakan desain kualitatif deskriptif untuk menentukan sikap siswa terhadap XReading. Hasil penelitian menemukan bahwa siswa memiliki sikap positif terhadap XReading. Oleh karena itu, dapat disimpulkan bahwa praktik ER menggunakan XReading dapat dilaksanakan dengan menyediakan dan mendorong mahasiswa untuk membaca lebih banyak materi bacaan akademik untuk mengembangkan pemahaman akademik.
\end{abstract}

Kata kunci: bacaan ekstensif, pemahaman membaca, sikap siswa, XReading

\section{Abstract}

This study aimed to identify the correlation between reading time in XReading and students' academic reading comprehension and find out students' attitudes toward XReading. A quantitative and qualitative approach were used to answer the problems. The participants of this study were first-year EFL college students who take part in extensive reading (ER) program with XReading as the assigned platform. The data were collected from the recorded time spent by students in XReading and their scores on a reading comprehension test. The test was adapted from a Reading Comprehension Test designed for advanced readers. The data were analyzed using Pearson Correlation and Linear Regression to determine how XReading contributes to reading comprehension. The results showed that reading time in XReading contributed to reading comprehension by about 10\%, yet there was no significant correlation between the two variables. In addition, Likert Scale questionnaires and interviews were analyzed using a descriptive qualitative design to determine the students' attitudes toward XReading. The results found that students have positive attitudes to XReading. Therefore, it could be concluded that ER practices using XReading can be implemented by providing and encouraging students to read more academic reading materials to develop academic comprehension.

Keywords: extensive reading, reading comprehension, students' attitudes, XReading.

Copyright (c) 2021 Alvin Nuril Hidayah, Anis Trisusana

$\triangle$ Corresponding author

Email : alvin.17020084064@mhs.unesa.ac.id

DOI : https://doi.org/10.31004/edukatif.v3i5.848

ISSN 2656-8063 (Media Cetak)

ISSN 2656-8071 (Media Online)

Edukatif : Jurnal Ilmu Pendidikan Vol 3 No 5 Tahun 2021 p-ISSN 2656-8063 e-ISSN 2656-8071 
2479 The Correlation Between Xreading Time Spent and Reading Comprehension \& Efl College Students' Attitudes Towards Xreading - Alvin Nuril Hidayah, Anis Trisusana

DOI: https://doi.org/10.31004/edukatif.v3i5.848

\section{INTRODUCTION}

Due to the number of textbook resources written in English, EFL college students are required to master fluent comprehension. While the urgency to achieve excellent comprehension is stressed, it is not supported with enough exposure to the target language (Grabe, 2009). As one of the critical roles in determining a significant level of comprehension, maximum exposure to the target language might be a helpful approach to raise the chance of achieving proficient comprehension.

Extensive reading has been introduced as one way to maximize students' exposure to reading (Bamford \& Day, 2004). Extensive reading is defined as an approach to teach language by allowing students to read a lot of materials of their own choice for enjoyment, seeking information, or for overall general meaning (Bakla, 2020). They further stated that extensive reading often refers to reading many materials for pleasure which benefits could be reached by assigning students to post-reading activities. Bamford \& Day (2004) introduces a set of the principles for a successful outcome in implementing extensive reading, namely the reading material is easy, a variety of reading material on a wide range of topics is available, learners choose what they want to read, learners read as much as possible, reading speed is usually faster than slower, the purpose of reading is usually related to pleasure, information, and general understanding, and reading is individual and silent.

Many scholars have suggested ER as an approach to develop sufficient reading ability for EFL students. It is proven by the number of studies conducted related to ER and its effects on reading ability. McLean found the effectiveness of extensive reading to develop reading rates. Daskalovska (2018); Green (2020); Shen et al. (2018) in their studies found that ER is an effective method in improving vocabulary acquisition. Cote \& Milliner (2014) had conducted a study to explore teachers' practice and students' attitudes towards extensive reading found that ER affected students' motivation and the number of books they read.

While the results of said studies showed a significant impact of ER on students' reading skill, it is still unknown how ER contribute to reading comprehension. Reading comprehension is a multi-component construct that includes vocabulary, literal understanding, interference making, and evaluative processes (Kärbla et al., 2020). In this era of growing technology, the traditional extensive reading program was gradually replaced by an online program due to its implementation that comes with huge costs (T Cote \& Milliner, 2014; Hinkelman, 2013). Education practitioners have shown their preferences for a more advanced and innovative extensive reading program in the form of a website called XReading. XReading is "an online library with hundreds of graded readers that is more accessible for students and easier for teachers to manage and access" (XLearning System, LLC, 2014). The unlimited readers provided by the website allows students to read various books from any genre based on their preferences and competencies. It helps the problems of paper-based extensive reading program that has limited resources. The easy-to-manage system is also helpful for teachers to monitor their students' reading progress.

As the website was only introduced in 2014, only a limited number of studies focused on issues related to XReading. Sartika (2020) examined the implementation of XReading as an extensive reading program in a university in Indonesia. However, the research merely focused on language skills in general and less emphasis on reading skills, so further study is needed to determine whether online ER practices benefit students' reading comprehension. According to Ciuffo et al. (2017), reading comprehension is the general purpose of reading for students, so it might represent students' reading skills.

However, the website's claims seem to be the opposite of what Tagane et al. (2018) found in their study. The study was conducted in Japan, and the results show that the paper-based method is more preferred than XReading due to the technical problems and the comprehension quizzes being too difficult to pass. On the other hand, the study was conducted by comparing two different methods (paper- and online-based), so the results might be less reliable than a study that focuses on the implementation of XReading itself. Furthermore, the interviews only covered the students' feelings towards the program and barely on how it influences their 
reading skill, which was achieved from general questions and barely on the detailed explanation of each essential skill. Another issue that needs to be addressed is that the subjects are from different geographical areas, which might result in different findings.

A study conducted by Cote \& Milliner (2015) showed a different result than the previous one. The study was also conducted in Japan to determine the students' attitudes towards the program and how XReading influences their reading speed and TOEIC scores. The results showed that students respond positively towards the program, and there was an increase in students' TOEIC scores who were able to increase their reading speed. On the other hand, this study focused more on students' reading speed rather than reading comprehension. Cote \& Milliner (2014) conducted another study in Japan that identify the influence of extensive reading on reading comprehension by comparing two mediums; printed books and XReading. However, the results show that students who read printed books and those on XReading have a similar average score on the reading comprehension test. However, most of the students still preferred printed books as they were still adjusting to XReading.

Although many studies claimed that reading comprehension could be developed through XReading, a study conducted by Anindita (2020) showed that students more preferred to read fiction books in XReading, rather than academic texts. The study was conducted on English Education students in the same university, reported that $80 \%$ of the students preferred novels. At the same time, academic books such as journals were only selected by one out of ten students being interviewed. Furthermore, non-academic books, especially fiction, are built from entirely different components from academic textbooks, including structures, vocabulary, and the content of the texts. Therefore, it was still unknown whether implementing XReading for developing students' comprehension levels was suitable as students mostly preferred reading non-academic books when participating in the program.

Addressing the gaps of previous studies might give more reliable and representative results and better understand the problem. Therefore, this study discussed the following questions:

1. Is there a positive relationship between reading time in XReading and students' reading comprehension? If so, to what extent does it contribute?

2. What are the students' attitudes to their experience using XReading?

\section{METHODS}

Although many studies claimed that reading comprehension could be developed through XReading, a study conducted by Anindita (2020) showed that students more preferred to read fiction books in XReading, rather than academic texts. The study was conducted on English Education students in the same university, reported that $80 \%$ of the students preferred novels. At the same time, academic books such as journals were only selected by one out of ten students being interviewed. Furthermore, non-academic books, especially fiction, are built from entirely different components from academic textbooks, including structures, vocabulary, and the content of the texts. Therefore, it was still unknown whether implementing XReading for developing students' comprehension levels was suitable as students mostly preferred reading non-academic books when participating in the program.

This study is a correlational study that aimed to identify the relationship between time spent by students reading all kinds of texts based on their preferences in XReading and their reading comprehension. According to Koosha et al. (2016), a correlational study describes the degree of relationship between two or more quantitative variables. In addition, a descriptive design is also used to describe and interpret the students' attitudes to the program.

The population of the study was first-year students enrolling in the XReading program. In determining the research sample, Clustered Sampling was used. Twenty-one first-year students from an English Education 
2481 The Correlation Between Xreading Time Spent and Reading Comprehension \& Efl College Students' Attitudes Towards Xreading - Alvin Nuril Hidayah, Anis Trisusana

DOI: https://doi.org/10.31004/edukatif.v3i5.848

study program in Universitas Negeri Surabaya were chosen to be the subject. The extensive reading program is designed by the department exclusively for first-year students. Furthermore, XReading is used as the platform starting from the previous year. Thus, the first-year students are suitable to be the subjects for all of them enrolling in the program.

The research was conducted on the second semester of the ER program, which meant that the participants had finished the ER practices for the first semester. During the program, students could read texts based on their preferences from various collections provided by XReading, which are categorized based on genres, formats, book levels, word counts, and so on. The data were collected by conducting tests and interviews as well as distributing questionnaires. A reading comprehension test was conducted to identify which comprehension level is the most potential to be developed through XReading. The test used was adapted from a reading comprehension test designed for advanced readers, which contained academic passages of about 200 - 400 words followed by comprehension questions. At the beginning of second semester, the test was conducted through an online platform due to a pandemic, which was impractical to conduct a test conventionally. Records of students' reading activities in XReading within the first period of the program (September - February) were also downloaded from the website. The data collected from the comprehension test were calculated along with the recorded time students read in XReading to identify a correlation between the extensive reading practices using XReading and students' reading comprehension. Regression was calculated to find out how far ER practices contribute to reading comprehension.

In order to collect students' attitudes to their experience using XReading, questionnaires were distributed through an online platform. The questionnaires were a Likert scale questionnaire in the form of sentences followed by choices that students have to answer based on how the statements best describe them: 'Strongly Agree', 'Agree', 'Neutral', 'Disagree', and 'Strongly Disagree'. Furthermore, interviews were administered to elicit in-depth information that further elaborated data from the questionnaires. At last, the students were asked to answer open-ended questions regarding the same matter; their experience using XReading.

\section{RESULTS AND DISCUSSION}

\section{Relationship between reading time in XReading and academic reading comprehension}

Table 1 shows descriptive statistics of the participants' reading time in XReading and their comprehension test scores. The shortest reading time duration was 186.4 minutes, while the most extended duration participants spend in XReading was 1185.42 minutes. The mean was 544.57 minutes, meaning that the average time students spend reading in XReading within six months of the program was approximately 9 hours.

Table 1. Descriptive statistics of the total reading time and score on the comprehension test

\begin{tabular}{llllll}
\hline & N & Min & Max & Mean & $\begin{array}{l}\text { Std. } \\
\text { Deviation }\end{array}$ \\
\hline $\begin{array}{l}\text { Total reading } \\
\text { time (min) }\end{array}$ & 21 & 186.54 & 1185.42 & 544.5710 & 216.99868 \\
\hline Test score & 21 & 16 & 28 & 22.95 & 3.201 \\
\hline
\end{tabular}

The hypothesis that more exposure toward target language (ER) resulted in better comprehension scores is assumed. Thus, this study applied a one-tailed correlation test. According to Table 2, there is no significant correlation between reading time in XReading and academic reading comprehension $(r=-0.327, p=.074<.05)$. 
2482 The Correlation Between Xreading Time Spent and Reading Comprehension \& Efl College Students' Attitudes Towards Xreading - Alvin Nuril Hidayah, Anis Trisusana

DOI: https://doi.org/10.31004/edukatif.v3i5.848

Table 2. Correlation of Reading Time in XReading and Academic Comprehension

\begin{tabular}{|c|c|c|}
\hline & & $\begin{array}{l}\text { Test } \\
\text { Score }\end{array}$ \\
\hline \multirow{3}{*}{$\begin{array}{l}\text { Reading Time } \\
(\min )\end{array}$} & Pearson Correlation & -0.327 \\
\hline & Sig. (1-tailed) & 0.074 \\
\hline & $\mathrm{N}$ & 21 \\
\hline
\end{tabular}

A regression model was run to calculate XReading's contribution to students' academic reading comprehension. As shown in Table 3, $\mathrm{R}$ was .327 , and the $\mathrm{R}$ square was 0.107 . This result indicated that reading time in XReading contributed to academic reading comprehension by 10.7 percent.

Table 3. Model Summary

\begin{tabular}{|c|c|c|c|c|}
\hline Model & $\mathbf{R}$ & $\begin{array}{c}\mathbf{R} \\
\text { Square }\end{array}$ & $\begin{array}{c}\text { Adjusted } \\
\text { R } \\
\text { Square }\end{array}$ & $\begin{array}{l}\text { Std. Error of } \\
\text { the Estimate }\end{array}$ \\
\hline 1 & $.327^{\mathrm{a}}$ & .107 & .060 & 3.10347 \\
\hline \multicolumn{5}{|c|}{ a. Predictors: (Constant), Reading time (min) } \\
\hline \multicolumn{5}{|c|}{ b. Dependent Variable: Reading comprehension } \\
\hline
\end{tabular}

The findings for the first research question reported that there is no significant correlation between the amount of time students spend reading in XReading and their academic reading comprehension ( $\mathrm{r}=-0.327$, $\mathrm{p}=.074<.05$ ). Moreover, the regression model showed that ER's contribution to academic reading comprehension was about $10 \%$, meaning that there is a stronger significant predictor than reading exposure. The result was in line with a study conducted by Song (2016) about the impact of ER practices on students' reading comprehension and vocabulary acquisition, which found that ER practices had little contribution in developing reading comprehension. Therefore, it can be concluded that ER practices might contribute to academic reading comprehension, but the contribution was low. Thus, there are other factors that need to be considered in enhancing academic reading comprehension.

\section{Students' attitudes towards XReading}

This study distributed the questionnaire to participants $(\mathrm{M}=7, \mathrm{~F}=14)$ after taking the comprehension test to identify students' attitudes of their experience using XReading. Data from questionnaires were analyzed by interpreting students' answers and the information obtained from the interviews. The first statement of the questionnaire sought to get information on students' general likeness in reading. As shown in Table 4, most students agreed that they like reading, while $23.4 \%$ remained neutral on the statements.

Table 4. I enjoy reading.

\begin{tabular}{lccccc}
\hline Statement & $\begin{array}{c}\text { Strongly } \\
\text { Agree }\end{array}$ & Agree & Neutral & Disagree & $\begin{array}{c}\text { Strongly } \\
\text { Disagree }\end{array}$ \\
\hline $\mathrm{N}$ & 5 & 11 & 5 & 0 & 0 \\
\hline Percentage & $23.8 \%$ & $52.4 \%$ & $23.8 \%$ & $0 \%$ & $0 \%$ \\
\hline
\end{tabular}

The second statement sought in detail whether they enjoy reading in XReading, compared to conventional printed books. Most participants agreed that they enjoy reading in XReading. While the previous statement has $23.8 \%$ of 'Strongly Agree' responses, the second statement shown a higher percentage by $33.3 \%$. It indicated that students enjoy preferred reading in XReading more than printed books. 
2483 The Correlation Between Xreading Time Spent and Reading Comprehension \& Efl College Students' Attitudes Towards Xreading - Alvin Nuril Hidayah, Anis Trisusana

DOI: https://doi.org/10.31004/edukatif.v3i5.848

Table 5. I enjoy reading in XReading.

\begin{tabular}{lccccc}
\hline Statement & $\begin{array}{c}\text { Strongly } \\
\text { Agree }\end{array}$ & Agree & Neutral & Disagree & $\begin{array}{c}\text { Strongly } \\
\text { Disagree }\end{array}$ \\
\hline $\mathrm{N}$ & 7 & 10 & 4 & 0 & 0 \\
\hline Percentage & $33.3 \%$ & $47.6 \%$ & $19 \%$ & $0 \%$ & $0 \%$ \\
\hline
\end{tabular}

The following statement was administered to find out their reason for enjoying XReading. Half of the participants agreed that they liked XReading for its features, $33.3 \%$ was strongly agreed, and $14.3 \%$ remained neutral on the statements. No responses stated that they disagreed with the statements.

Table 6. I enjoy reading in XReading because of its features.

\begin{tabular}{lccccc}
\hline Statement & $\begin{array}{c}\text { Strongly } \\
\text { Agree }\end{array}$ & Agree & Neutral & Disagree & $\begin{array}{c}\text { Strongly } \\
\text { Disagree }\end{array}$ \\
\hline $\mathrm{N}$ & 7 & 11 & 3 & 0 & 0 \\
\hline Percentage & $33.3 \%$ & $52.4 \%$ & $14.3 \%$ & $0 \%$ & $0 \%$ \\
\hline
\end{tabular}

The next question was presented to seek in-depth information on which features that they enjoy in XReading. $81 \%$ of participants answered they like the reading performance information (reading speed, reading time, word count, book level, and more) provided by the website. $76.2 \%$ stated that they like the vast collections that allow them to choose books from various genres, which related to $66.7 \%$ responses which stated that it allowed them to choose books based on their preferences. Audiobook and comprehension quizzes were the two least preferred by $47.8 \%$ and $38.1 \%$ of responses.

Table 7. Which feature( $s$ ) in XReading that you enjoy? (You can choose more than one)

\begin{tabular}{lcc}
\hline \multicolumn{1}{c}{ Features } & F & M \\
\hline Self-selected materials & $8(38.1 \%)$ & $6(28.6 \%)$ \\
\hline $\begin{array}{l}\text { Huge collections and various } \\
\text { genres }\end{array}$ & $10(47.6 \%)$ & $6(28.6 \%)$ \\
\hline $\begin{array}{l}\text { Reading performance } \\
\text { information }\end{array}$ & $8(38.1 \%)$ & $7(33.3 \%)$ \\
\hline Audiobook & $8(38.1 \%)$ & $2(0.1 \%)$ \\
\hline Comprehension quizzes & $5(23.8 \%)$ & $3(0.2 \%)$ \\
\hline
\end{tabular}

This study conducted interviews to support the data from the questionnaires. The students' answers from the interview explained why they less enjoy both features. Regarding the comprehension questions, the responses had the same conclusion: the questions were too basic and less challenging. In addition, students rarely played the audiobooks because they preferred to read in silence, and those who used the feature didn't find the audiobook they needed.

Table 8. Students' Interview Answers about Comprehension Quizzes

"I think it's too easy." [DS_S7_21]

"The questions are too basic. I think they need to increase the level, so the questions are more challenging to answer." [IQ_S13_21] 
2484 The Correlation Between Xreading Time Spent and Reading Comprehension \& Efl College Students' Attitudes Towards Xreading - Alvin Nuril Hidayah, Anis Trisusana

DOI: https://doi.org/10.31004/edukatif.v3i5.848

"It's below my expectation because the first time I read in XReading, I read 20,000 words book, and I took notes on the important points, but the questions were too simple. I am sure I could answer it without taking notes. To sum up, it's too easy." [NA_S16_21]

Table 9. Students' Interview Answers about Audiobooks

"They need to add the audiobook collection because I once tried to find the audiobook for the book I'm currently reading, and it wasn't available." [IQ_S13_21]

"I only played it once, and it's a short text. I do not really like reading while playing the audiobook because it affects my concentration. I like to read in silence." [NA_S16_21]

The next question aimed to measure how XReading improves English ability from the students' perception. As demonstrated in Table 10, nearly all participants stated that reading in XReading increased their vocabulary size. Next in line was their general understanding by $76.2 \%$ responses. Half of the students (52.4\%) claimed that their reading speed increased, while $42.9 \%$ said reading in XReading improved their grammar. Only a limited number of students stated that XReading improved their listening and speaking skills. These were related to their answers to the previous question, which showed that they rarely used the audiobook feature for lack of interest or incomplete collections. This finding explained the lack of improvement in listening and speaking.

Table 10. Which area(s) do you think improving? (You can choose more than one area)

\begin{tabular}{lcc}
\hline \multicolumn{1}{c}{ Features } & F & M \\
\hline Reading speed & $6(28.6 \%)$ & $5(23.8 \%)$ \\
\hline Vocabulary & $14(67 \%)$ & $6(28.6 \%)$ \\
\hline Grammar & $6(28.6 \%)$ & $3(0.2 \%)$ \\
\hline General understanding & $9(42.9 \%)$ & $7(33.3 \%)$ \\
\hline Listening & $4(19.1 \%)$ & $2(0.1 \%)$ \\
\hline $\begin{array}{l}\text { Speaking (and/or } \\
\text { pronunciation) }\end{array}$ & $5(23.8 \%)$ & $3(0.2 \%)$ \\
\hline
\end{tabular}

The last statements sought to find out whether students planned to continue using XReading after the program ends. $33.3 \%$ agreed to continue using XReading, while $14.3 \%$ strongly agreed. However, about half the students remained neutral on the statements and even $9.5 \%$ do not plan on continue using XReading.

Table 11. I will continue using XReading on my own after the program ends.

\begin{tabular}{lccccc}
\hline Statement & $\begin{array}{c}\text { Strongly } \\
\text { Agree }\end{array}$ & Agree & Neutral & Disagree & $\begin{array}{c}\text { Strongly } \\
\text { Disagree }\end{array}$ \\
\hline $\mathrm{N}$ & 3 & 7 & 9 & 2 & 0 \\
\hline Percentage & $14.3 \%$ & $33.3 \%$ & $42.9 \%$ & $9.5 \%$ & $0 \%$ \\
\hline
\end{tabular}

This study asked an open-ended question to understand their reasons for deciding to continue the subscription. According to their answers as presented in Table 12, participants who 'Strongly Agreed' to continue using XReading after the program ends said they prefer reading in XReading because it improved 
2485 The Correlation Between Xreading Time Spent and Reading Comprehension \& Efl College Students' Attitudes Towards Xreading - Alvin Nuril Hidayah, Anis Trisusana

DOI: https://doi.org/10.31004/edukatif.v3i5.848

their reading motivation and English skills. On the contrary, participants who 'Disagreed' stated they couldn't afford the subscription fee, and the website didn't have enough collections to cover their interests.

Table 12. Students' Interview Answers about XReading Subscription

I chose to continue because it is simpler and more relaxed whenever I want to read a book. [AA_S1_21]

Because I never find platforms that can make me feel that reading is not only a boring activity, but also fun. [AD_S2_21]

I want to improve my English. [EF_S9_21]

Because when the program ends, the payment will be back (to normal), and it costs not cheap. I also seldom read because I don't like to read that much. [HS_S12_21]

Because XReading doesn't have variations in books such as comics or anything that leads me interested in XReading, and the other reason is, the books are too old for me. [NA_S16_21]

The result of Table 4 indicated that students had a good perception of reading, and it was emphasized with more "Agreed" responses Table 5, which meant that their perception of reading was better when they used XReading. However, this result was against what Cote \& Milliner (2015) revealed in their study, which reported that only a small number of students enjoyed their experience reading graded readers in XReading. Table 6 and Table 7 showed that its features elicited students' good perception towards XReading. It was in line with the principles in implementing ER presented by Bamford \& Day (2004), namely "a variety of reading material on a wide range of topics" and "learners choose what they want to read". However, the responses to open-ended questions in Table 8 and Table 9 showed that students found some XReading' features less enjoyable. This study found that comprehension quizzes were too easy. It supported findings from a previous study conducted by Collett (2018) which reported that quizzes in XReading were shorter and easier to pass than quizzes in M-Reading. With this finding, it is suggested for the web developer to enhance their comprehension quizzes for more significant results in ensuring students' comprehension of the text and elevating their attitudes towards the feature.

Table 10 indicated that students felt their reading skills had improved. This finding was in line with Tagane et al. (2018) who reported that students felt an improvement in their vocabulary sizes and general comprehension. Moreover, their study stated that students also improved their reading speed, which was in line with Howarth \& Bollen (2019), who reported that students felt ER increased their reading speed and improved overall reading ability. However, only a little more than half of the students in this study felt the same way. The last item in Table 11 showed that only a little over half of the students planned to continue using XReading independently. Howarth \& Bollen (2019) also find similar findings. According to them, this finding was alarming as their experiences in XReading hadn't elicited pleasurable feelings towards reading. This study found different reasons why they hesitate to continue using XReading. Students said that they would undoubtedly continue their subscription if they do not have to pay the fee. It indicated that students' hesitation wasn't caused by XReading's unsuccessful attempt to ensure students' good attitudes towards reading. Therefore, it can be concluded that students have good attitudes towards their experience using XReading. With such findings, it is possible to build students' academic reading comprehension through ER practices using XReading because students' have positive attitudes towards the program. Moreover, students' positive attitudes towards XReading might increase ER practices' contribution in developing academic reading comprehension. Despite most of the materials read by students were non-academic texts, the regression result showed that reading in XReading contributes to academic reading comprehension by $10 \%$. Therefore, the 


\section{The Correlation Between Xreading Time Spent and Reading Comprehension \& Efl College Students' Attitudes Towards Xreading - Alvin Nuril Hidayah, Anis Trisusana \\ DOI: https://doi.org/10.31004/edukatif.v3i5.848}

percentage could increase if the students are encouraged to read more academic books by providing more comprehensive textbooks than non-academic books.

Referring to the results of the first question, although there was no significant correlation between reading time in XReading and academic reading comprehension, students showed good attitudes towards XReading and claimed that XReading improved their reading abilities (speed, grammar, vocabulary, general understanding). In addition, these findings could be used as insights for future implementation of ER practices using XReading and for further development of students' academic reading comprehension. However, some limitations need to be addressed in concluding the results. This study calculated the link between reading time in XReading and EFL college students' reading comprehension, so the results might not represent other factors that may contributes to reading comprehension. Hence, future studies need to determine which factor has significant contribution to reading comprehension among college students. Moreover, the improvements that students' felt in their reading ability were solely based on their answers to questionnaires and interviews. Therefore, the results from future studies that administer several tests are needed to show whether students claims are inline with their actual reading ability.

\section{CONCLUSION}

There is no significant correlation between reading time in XReading and EFL students' academic reading comprehension $(\mathrm{r}=-0.327, \mathrm{p}=.074<.05)$. In addition, XReading contribution to reading comprehension was about $10 \%$. Despite no significant correlation was found between reading time and reading comprehension, students give positive attitudes to their experience in ER practices using XReading. Their positive attitudes were supported by their claims that they felt some improvements in their reading ability after participating in ER practices with XReading, namely 1) reading speed, 2) grammatical skill, 3) vocabulary size, and 4) general understanding. Therefore, it can be concluded that XReading is a suitable media for ER practices although different factors might give more contribution to academic reading comprehension than reading time. In referring to the findings, this study suggests 1) For web developers to enhance the comprehension quizzes level and expand the audiobook collections to improve user experience, 2) For teachers/lectures to encourage their students to read more academic texts in implementing ER practices, and 3) The writers hope this study could add insights to the body of knowledge and for fellow researchers to use this study as a reference for their future research.

\section{REFERENCES}

Anindita, C. (2020). EFL Students' Perception Towards Extensive Reading Practices In Higher Education Level.

Bakla, A. (2020). Extensive Reading And Web 2.0 Tools In Tandem: A Mixed-Methods Study. Education And Information Technologies, 25(4), 3131-3160. Https://Doi.Org/10.1007/S10639-020-10103-9

Bamford, J., \& Day, R. R. (2004). Extensive Reading Activities For Teaching Language.

Ciuffo, M., Myers, J., Ingrassia, M., Milanese, A., Venuti, M., Alquino, A., Baradello, A., Stella, G., \& Gagliano, A. (2017). How Fast Can We Read In The Mind? Developmental Trajectories Of Silent Reading Fluency. Reading And Writing, 30(8), 1667-1686. Https://Doi.Org/10.1007/S11145-0179744-2

Collett, P. (2018). A Comparison Of Two Online Systems For Extensive Reading. Journal Of Extensive Reading, 6(3). Http://Jalt-Publications.Org/Content/Index.Php/Jer/ 
2487 The Correlation Between Xreading Time Spent and Reading Comprehension \& Efl College Students' Attitudes Towards Xreading - Alvin Nuril Hidayah, Anis Trisusana

DOI: https://doi.org/10.31004/edukatif.v3i5.848

Cote, T, \& Milliner, B. (2014). Extensive Reading On Mobile Devices: Is It A Worthwhile Strategy? Proceedings Of The 12th Asia TEFL And 23rd MELTA International Conference, August, 979-990. Www.Xreading.Com

Cote, Travis, \& Milliner, B. (2015). Implementing And Managing Online Extensive Reading: Student Performance And Perceptions. IALLT Journal Of Language Learning Technologies, 45(1), 70-90. Https://Doi.Org/10.17161/Iallt.V45i1.8550

Daskalovska, N. (2018). Extensive Reading And Vocabulary Acquisition. The Idea And Practice Of Reading. Https://Doi.Org/10.1007/978-981-10-8572-7

Grabe, W. (2009). Reading In A Second Language. Cambridge University Press.

Green, C. (2020). Extensive Reading And Viewing As Input For Academic Vocabulary: A Large-Scale Vocabulary Profile Coverage Study Of Students' Reading And Writing Across Multiple Secondary School Subjects. Lingua, 239. Https://Doi.Org/10.1016/J.Lingua.2020.102838

Hinkelman, D. (2013). Blending Technologies In Extensive Reading: Moodlereader In A Japanese University EFL Program. In S. Miles \& M. Brierley (Eds). Extensive Reading World Congress Proceedings, 91100 .

Howarth, M., \& Bollen, D. (2019). Student Perception Of Online Extensive Reading Platform. Procedings Of Sojo University Vol. 44, 145-152.

Kärbla, T., Männamaa, M., \& Uibu, K. (2020). Vocabulary And Text Comprehension Levels: What Should Be Considered In Assessments? Educational Psychology, 40(7), 875-892. Https://Doi.Org/10.1080/01443410.2019.1703172

Koosha, M., Abdollahi, A., \& Karimi, F. (2016). The Relationship Among EFL Learners' Self-Esteem, Autonomy, And Reading Comprehension. Theory And Practice In Language Studies, 6(1), 68. Https://Doi.Org/10.17507/Tpls.0601.09

Sartika, A. C. (2020). Students' Perception Toward The Implementation Of Extensive Reading Program Using Xreading.

Shen, W. W., Lin, J. M., \& Hong, Z. W. (2018). An Extensive Reading System Built On The Basis Of Comprehensible Input Principles - A Key To Rescuing The Lower-Level EFL University Students' Vocabulary Ability. In Lecture Notes In Computer Science (Including Subseries Lecture Notes In Artificial Intelligence And Lecture Notes In Bioinformatics): Vol. 11003 LNCS (Issue I). Springer International Publishing. Https://Doi.Org/10.1007/978-3-319-99737-7_57

Song, M. (2016). The Impact Of Extensive Reading On EFL Primary School Students' Vocabulary Acquisition And Reading Comprehension. Extensive Reading World Congress Proceedings, 5(1983), 60-69.

Tagane, Y., Naganuma, N., \& Dougherty, P. (2018). Xreading Versus Paper-Based Extensive Reading: Perceptions Of Students. 77-97. Https://Doi.Org/10.1007/978-981-10-8264-1_5

Xlearning System, LLC, \& E. I. (2014). About Xreading. Xreading.Com/Pages/Helpcenter/About_Xreading 